\title{
Ethical Sourcing: An Analysis of the Literature and Implications for Future Research
}

\author{
Seongtae $\mathrm{Kim}^{1} \cdot$ Claudia Colicchia $^{1} \cdot$ David Menachof $^{1}$
}

Received: 25 November 2015 / Accepted: 8 July 2016/Published online: 20 July 2016

(C) The Author(s) 2016. This article is published with open access at Springerlink.com

\begin{abstract}
The purpose of this study is to present a rigorous, focused review on how this field of ethical sourcing research has grown and evolved over the decades, providing implications for future research. We combine two research methodologies in this study: a systematic literature review and a citation network analysis. The former is used as a scientific tool to select the most relevant ethical sourcing articles, while the latter is then applied as a research technique to analyse these selected articles. Such a combined approach allows for a rigorous investigation into this field of research in a more scientific and objective way. Based on this approach, we identify (1) distinctive features of ethical sourcing studies such as growth trends and content issues; (2) important articles that have played a significant role in developing this field; (3) evolutionary paths that show how its knowledge has been created and transferred; (4) emerging trends that have received growing attention in the recent literature; (5) main research areas that underlie the entire ethical sourcing studies; and (6) major implications that need to be pursued in future research. The results of this study provide not only the current status of the literature but also the patterns of evolution in this field of research, thus contributing to the existing literature.
\end{abstract}

Seongtae Kim

esrskim@gmail.com

Claudia Colicchia

c.colicchia@hull.ac.uk

David Menachof

d.menachof@hull.ac.uk

1 Hull University Business School, University of Hull, Kingston upon Hull HU6 7RX, UK
Keywords Citation network analysis - Corporate social responsibility · Ethical sourcing · Sustainable sourcing · Sustainable supply chain management $\cdot$ Systematic literature review

\section{Introduction}

After a series of infamous scandals, many multinational firms have now recognised the importance of ethical sourcing. For example, in the aftermath of the child labour scandal in 1996, Wal-Mart announced a plan that they would improve working conditions at its supplier facilities around the world (Strom 1996). Another well-known case was Nike; however, it was by no means all smooth sailing. A story about Nike's sweatshop came out in earnest in 1996, when Life magazine published an article about child labour in Pakistan (Banjo 2014). Despite harsh criticism for its ethical fecklessness, Wal-Mart and Nike greatly improved their image so that they are now seen as leaders in social responsibility.

In this study, we refer to ethical sourcing as managing all processes of supplying the firm with required materials and services from a set of suppliers in an ethical and socially responsible manner. The term ethical sourcing is often used interchangeably with other similar terms such as socially responsible buying (e.g. Maignan et al. 2002), socially responsible sourcing (e.g. Zorzini et al. 2015), and purchasing social responsibility (e.g. Carter and Jennings 2002). Each term has been defined in a unique and specific way. However, the basic concept is similar in the aspect of describing the involvement of business in sourcing decisions that cover ethical, social, and economic issues. Indeed, they are similar to the broader term sustainable sourcing, which is in line with the triple bottom line 
concept. That is, organisational sustainability can be achieved only through the combination of social (people), environmental (planet), and economic (profit) performance.

There have been a growing number of literature reviews that address sustainable issues in the field of operations and supply chain management (OSCM). However, there are still limitations. First, most previous reviews are largely focused on generic sustainable supply chain management (e.g. Seuring and Müller 2008; Carter and Easton 2011; Winter and Knemeyer 2013). This narrow focus calls for research into other aspects (e.g. ethical issues) of the supply chain, which are relatively ignored. Second, sustainability in the upstream has received increasing attention in literature; however, little research has been performed to evaluate its current status. Third, although a few works have been recently carried out, most of them are focused only on either sustainable (Hoejmose and Adrien-Kirby 2012; Miemczyk et al. 2012) or environmental issues (Tate et al. 2012; Genovese et al. 2013; Appolloni et al. 2014). Much less is known about its social aspect. Zorzini et al. (2015) provides an extensive review on this under-researched topic, with a particular goal of analysing its use of theory. However, the authors fail to make predictions regarding where this field may be headed, which we aim to overcome with our study.

Clearly, prior literature reviews on sustainable sourcing are not extensive enough, particularly in the people-side of sustainability. This gap is more apparent when it comes to the evolutionary aspect of this field. This leads us to complement existing studies by providing a rigorous, focused review on its social aspect, namely ethical sourcing. This study thus attempts to provide the current status of ethical sourcing studies, as well as advancing our understanding on how this field has evolved over time. For these aims, we seek in this study to identify (1) distinctive features of ethical sourcing studies; (2) important articles that have played a significant role in developing this field; (3) evolutionary paths that show how its knowledge has been created and transferred; (4) emerging trends that have received growing attention in the recent literature; (5) main research areas that underlie the entire ethical sourcing studies; and (6) major implications that need to be pursued in future research. This is a timely study, given that ethical issues (e.g. sweatshop) in sourcing operations have been a major challenge to business, and that relevant studies have also rapidly increased. We believe that this study will provide a sense of its future.

The novelty of this study also lies in methodological rigour. This study uses a unique method called systematic literature network analysis (SLNA), proposed by Colicchia and Strozzi (2012). Basically, this approach combines two research techniques: a systematic literature review (SLR) and a citation network analysis (CNA). The SLR is used in this study as a scientific tool to select the most relevant ethical sourcing articles, while CNA is used as a research technique to analyse its bibliographic data. SLNA has been successfully applied in the OSCM field (e.g. Strozzi and Colicchia 2015). However, this approach has not been used in the area of ethical sourcing, despite its potential value which can identify the evolution of thought in the subject. Compared with a traditional review, SLNA is beneficial in terms of analysing ethical sourcing studies in a more scientific and objective way. Furthermore, it allows us to better determine the nature of ethical sourcing studies (e.g. knowledge structure), thus giving a foundation to this research field. It can thus be argued that our findings should help researchers assess avenues for future studies with greater objectivity.

This study is organised as follows. Section 2 describes the research methodology used in this study to identify and evaluate the most relevant articles in the area of ethical sourcing. Some analytical techniques are also briefly described in this section. Section 3 presents descriptive findings including basic, content, and other statistics. Section 4 provides the results of network analysis, showing the knowledge and topical structure of existing ethical sourcing studies with its development trajectories. Section 5 suggests major implications for future ethical sourcing research. Section 6 presents study conclusions.

\section{Research Methodology}

\section{Data Collection: Systematic Approach}

Denyer and Tranfield (2009), p. 671 refer the SLR as "a specific methodology that locates existing studies, selects and evaluates contributions, analyses and synthesizes data". Unlike a traditional, narrative literature review, the SLR is carried out in a way that is scientific and transparent, thus helping limit researcher bias in all aspects of the review process. Based on previous studies (Rashman et al. 2009; Carter and Easton 2011), the SLR approach used in this study consists of the following major steps.

\section{Database Selection}

This study collected sample articles and its associated citation data from the Web of Science. The Web of Science is one of the well-established citation databases provided by Thomson Reuters, covering over 12,000 high impact peer-reviewed journals. It should be noted that data for this study are also available in Elsevier's Scopus. This journal coverage is more extensive than the Web of Science; however, they are only complete from 1996 onward. This means that Scopus is limited to recent articles, and 
therefore, some articles in earlier research could be missing. For this reason, we chose the Web of Science as a selected database in order to fulfil our purpose of providing a focused review on this field of research over the last decades.

\section{Article Selection}

To capture our sample articles, we first developed a basic set of keywords (e.g. ethic ${ }^{*}$ sourcing) by conducting brainstorming sessions with two academics and three doctorate students having experience in business. We then used these preliminary keywords in database search to collect an initial set of articles, helping us to identify additional keywords that are frequently used in this field. We subsequently refined these keywords with two other independent academics in order to validate our search. As a result, the final set of keywords used in combination includes 'ethic", 'sustainab", 'social",, 'responsib", 'sourcing', 'purchasing', 'procurement', 'trade', 'supplier', 'supply', 'supply chain', 'fair trade', 'ethical trade', 'sweatshop', 'labo?r standard", 'labo?r rights', 'worker rights', and 'human rights'. In this process, we only considered peer-reviewed journal articles in order to reduce its bibliographic data to a manageable level. This database search (conducted in March 2014) resulted in 7260 initial references.

\section{Article Evaluation}

We then assessed each paper of the initial set of retrieved articles screening the titles, keywords, and abstracts. In this step, we set a series of inclusion and exclusion criteria to only capture articles relevant to ethical sourcing. Specifically, for articles to be included, they had to address ethical issues in the context of supply management. Therefore, irrelevant topics (e.g. consumer studies) and generic supply chain studies were excluded from the initial dataset. Most of the initial references eliminated fell into this category. Green-focused sourcing research was also excluded; however, if these studies addressed social issues equally, they were included in our dataset. We also decided to exclude articles addressing fair/ethical trade, human rights, sweatshop subjects, unless there was a clear link to sourcing operations. These steps reduced the initial references to 155 articles that have been published from 1979 to 2013, spread across 58 peer-reviewed journals.

\section{Coding}

The 155 collected articles were then coded into a database in Microsoft Excel, in terms of general information (authors' name, title of article, year of publication, and journal name) and self-developed categories such as industry sector, discipline base, research method, and performance issue. Two of the authors were involved in this process in order to avoid being subjective that can result in bias. Moreover, the initial result of coding was then validated by the other author, helping to restrict the subjective bias. This process was iterative until the agreement was reached between authors.

\section{Analysis of the Bibliographic Data}

This study conducts two major analyses, i.e. a descriptive and a network analysis, for the focused review of the literature. The descriptive analysis comprises several subsections, which are conducted by various software packages. Specifically, after coding each article, we analyse the collected articles in terms of content issues using Microsoft Excel. We then organise its associated citation data using HistCite software to analyse other descriptive statistics such as popular keywords in the literature. We also apply "Loglet" analysis to a cumulative number of articles published to identify the growth trend of ethical sourcing literature. This analysis was conducted by the Loglet Lab 2 software package (Meyer et al. 1999).

This study uses Pajek 2.05 software package for examining citation network and its main paths as presented in network analysis. Pajek is chosen for this study as it is one of the most well-known software packages designed for various analyses of the network data, including citation network and main paths. However, Pajek does not offer Girvan-Newman algorithm, which is useful for detecting community structures within citation networks. For this reason, we also employ the software package called Ucinet 6 for cluster analysis. Data clustering using Ucinet would help us to better detect details of the subareas of ethical sourcing studies, providing unique insights into this field. In the remainder of this section, we briefly outline the analyses conducted in this study.

\section{Loglet Analysis}

Loglet analysis is designed to analyse sets of existing timeseries data for capturing its growth and diffusion trends. The underlying assumption of Loglet analysis is that the measured quantity (e.g. animal populations) in a natural or social system cannot grow infinitely, thus following an S-shaped curve. The growth of a body of literature can also be represented by its 'life cycle' concept. That is, the number of articles in a research area increases slowly at the beginning, but it starts growing exponentially before entering a saturation phase. The number of articles decreases in the end as interest in that area disappears gradually. 
Using the software Loglet Lab 2 (Meyer et al. 1999), we analyse an S-shaped growth of our time-series dataset, which is fitted to a logistic model of the following form:

$N(t)=\frac{\kappa}{1+\exp \left[-\frac{\ln (81)}{\Delta t}\left(t-t_{\mathrm{m}}\right)\right]}$,

where $\kappa$ is the asymptotic limit of the growth curve; $\Delta t$ is the characteristic duration, a period that specifies the time required for the growth trajectory of the asymptotic limit $\kappa$; and $t_{\mathrm{m}}$ is the midpoint of its growth trajectory. These three parameters define the parameterisation of its model, which is used as the base for Loglet analysis.

\section{Main Path Analysis}

Main path analysis is one of the special techniques for citation network proposed by Hummon and Doreian (1989). Using citation data, this particular approach is especially designed for identifying the development of knowledge in a scientific literature while taking into account the flow of time. The main path analysis is also known for highlighting the vital articles that have contributed to its literature, thus establishing a baseline for identifying how this field has evolved over time. This is particularly useful in a relatively large citation network where there is much difficulty in identifying the main flow of knowledge.

In a citation network, each article represents each node (i.e. depicted as a circle), while citation data represent the links among nodes (in our case, 155 nodes in total). A source is a node that is not citing others, whereas a sink is a node that is not cited by others. This means that the source(s) are the starting nodes of, and the $\operatorname{sink}(\mathrm{s})$ are the ending nodes of a citation network. Main path analysis is also based on computing the extent to which a particular citation is necessary for linking nodes (articles), i.e. the traversal weight of a citation. To sum up, the main path in a citation network is a path from a starting node (i.e. source) to an ending node (i.e. sink) with the highest traversal weights (i.e. the proportion of all paths between source and sink nodes) on its links.

Broadly speaking, there are three major steps to perform the analysis using Pajek 2.05 (Colicchia and Strozzi 2012). The first step is to calculate the traversal weight of the citation using one of the three methods featured in Pajek: Search Path Count, Search Path Link Count, and Search Path Node Pair. The method chosen in this study is the Search Path Count because it counts all paths between each source and sink. The others are only recommended when specific node(s) are more important, which does not apply to this study. The second step is to extract the main paths from the citation network using its calculated traversal weights. The last step is to extract the main path component using a cut-off value between 0 and 1 . The value used in this study is 0.5 which is the default. For more details, interested readers can refer to de Nooy et al. (2011).

\section{Cluster Analysis}

Cluster analysis is used in this study in order to detect details of the clusters within the citation network. We use Girvan-Newman algorithm to discover sets of nodes that are densely connected to each other but loosely connected to the others. This algorithm is based on modularity $Q$, which is the value designed to test whether a particular division into clusters is meaningful. The modularity $Q$ can be measured by

$Q=\sum_{i}\left(e_{i i}-a_{i}^{2}\right)=\operatorname{Tr}(e)-\|e\|^{2}$,

where $e_{i j}$ is the fraction of the links in the network that connect nodes in cluster $i$ to those in cluster $j$, and $a_{i}=\sum_{j} e_{i j} ; \operatorname{Tr}(e)$ represents the sum of the density of links within each cluster. Here, the minimum value of $Q$ is 0 , which means the number of within-cluster links is no better than random chance, while the maximum value is 1 . Therefore, a high value of $Q$ indicates a good division of a network, which has only dense connections within clusters. In general, the value of $Q$ falls in the range of approximately $0.3-0.7$. For more details, we refer interested readers to Newman (2004) and Newman and Girvan (2004).

\section{Descriptive Findings}

\section{Basic Statistics}

Table 1 presents a list of major journals identified in database search. Most of the selected articles (44, $28.4 \%)$ are published in business ethics journals (i.e. $J B E$ and $B E Q$ ), where 40 articles $(25.8 \%)$ are from $J B E$. About two-thirds of the total articles $(43,27.7 \%)$ are published in OSCM journals (i.e. SCMIJ, IJPE, JPSM, JCP, JOM, and $J S C M)$, where 14 articles $(9.0 \%)$ are from SCMIJ. Overall, the major journals presented in the table have contributed to the publication of 93 articles in total, which account for $58.0 \%$ of the selected articles.

Figure 1 shows the number of articles published from 1979 to 2013, representing a 35-year time horizon. During a given time period, the number of articles grew steadily, increasing from one in 1979 to 13 articles in 2013. The greatest number of articles was published in 2012 (24 articles), while no and relatively very few publications appeared in early years. On the whole, however, there has 
Table 1 List of major journals (of 58) contributing to this field

\begin{tabular}{lc}
\hline Journal (acronym) & No. of articles \\
\hline Journal of Business Ethics (JBE) & 40 \\
Supply Chain Management: An International Journal (SCMIJ) & 14 \\
International Journal of Production Economics (IJPE) & 9 \\
Journal of Purchasing and Supply Management (JPSM) & 7 \\
Industrial Marketing Management (IMM) & \multicolumn{2}{|c}{6} \\
Journal of Cleaner Production (JCP) & 6 \\
Business Ethics Quarterly (BEQ) & 4 \\
Journal of Operations Management (JOM) & 4 \\
Journal of Supply Chain Management (JSCM) & 4 \\
Other & 3 \\
Total & 62 \\
\hline
\end{tabular}

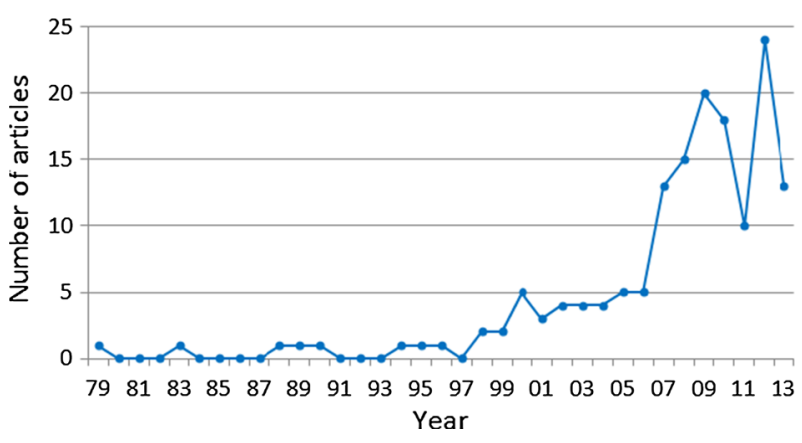

Fig. 1 Distribution of articles by year of publication

been a substantial increase in the number of articles over the last 35 years. In particular, from the late 1990s, more than 147 articles were published in this field, which account for $94.8 \%$ of the total.

This exponential increase may stem from a series of major scandals that occurred in business: Nike's child labour scandal in the late 1990s, which was criticised by the public for having underage labour at its overseas suppliers, especially in Pakistan; Starbuck's unfair trade scandal in the early 2000s, which was blamed for making huge profits at the coffee grower's expense; Apple's Foxconn employee suicide scandal in the late 2000s, which was severely accused of having terrible working conditions inside Chinese factories (cf. Argenti 2004; Zadek 2004; Chan et al. 2013). It should also be noted that recently there have been several special issues of journals devoted to ethical sourcing-related topics. Notably, two special issues have appeared in 2009 (JSCM and SCMIJ) and two in 2012 (IJPE and JPSM), accounting for the noticeable article frequency shown in Fig. 1. This trend clearly reflects the growing popularity of ethical sourcing studies in recent years.

On top of that, to discover the growth trend of its literature, we conduct the Loglet analysis on the cumulative number of articles using the software Loglet Lab 2. The

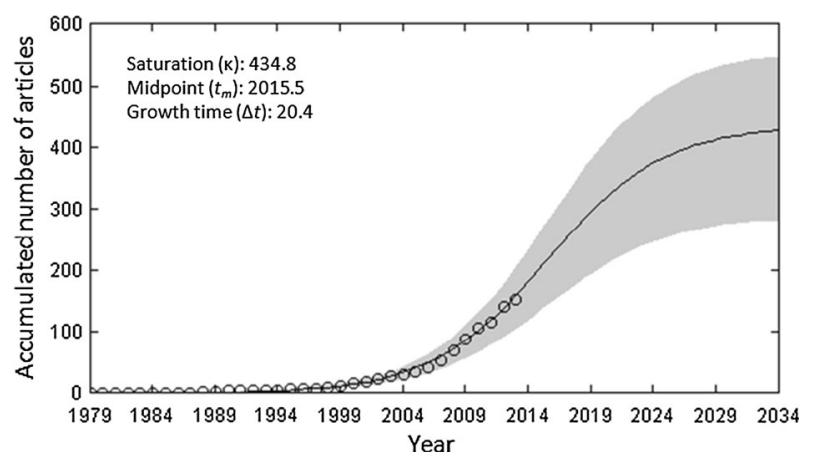

Fig. 2 Growth of ethical sourcing studies

result is visually shown in Fig. 2, where estimates of three parameters (i.e. $\kappa, t_{\mathrm{m}}$, and $\Delta t$ ) are presented in its top-left corner. The grey area surrounding the growth curve represents the $90 \%$ CI for the parameters. As Fig. 2 shows, there are only a few articles published for early years from 1979 to 2004, in which period indicates the birth phase of its growth trajectory. Then, the growth of this field began to increase in around 2005, and is predicted to reach its midpoint a decade later in 2015 . The saturation point of its growth trend is the year 2025, in which the number of articles is expected to be about 434 . Taken together, this field of research is still at a growth stage (near midpoint), indicating an ongoing growth of the literature. This growth is expected to last until around 2025 with more than 400 ethical sourcing articles, three times larger than the current situation.

\section{Content Statistics}

Table 2 shows the current status of the ethical sourcing literature, which is analysed in terms of industry sector, discipline base, research method, and performance issue. The first column of Table 2 shows the breakdown of ethical sourcing studies into two broad industrial categories: 
Table 2 Results of content statistics $(n=155)$

\begin{tabular}{|c|c|c|c|}
\hline Industry sector & Discipline base & Research method & Performance issue \\
\hline Manufacturing (62.6\%) & OSCM $(40.6 \%)$ & Qualitative (54.8\%) & Non-financial (22.6 \%) \\
\hline Textile goods (20.6\%) & Other disciplines (59.4\%) & Case study $(25.2 \%)$ & Financial $(1.9 \%)$ \\
\hline Food $(4.5 \%)$ & Marketing (15.5\%) & Conceptual work (15.5\%) & Not-applicable $(75.5 \%)$ \\
\hline Multi-industry (25.8\%) & Economics $(12.9 \%)$ & Interview (11.6\%) & \\
\hline Other $(11.6 \%)$ & Strategy $(11.0 \%)$ & Review (1.9\%) & \\
\hline Services $(14.2 \%)$ & Politics $(5.2 \%)$ & Ethnography (0.6) & \\
\hline Retail $(5.2 \%)$ & Industrial relations $(4.5 \%)$ & Quantitative (38.1\%) & \\
\hline Multi-industry (5.2 \%) & Geography (1.9 \%) & Survey $(27.7 \%)$ & \\
\hline Other $(3.9 \%)$ & Philosophy (1.9\%) & Database $(7.7 \%)$ & \\
\hline \multirow[t]{3}{*}{ None $(23.2 \%)$} & Other $(6.5 \%)$ & Math modelling $(1.3 \%)$ & \\
\hline & & Experiment $(1.3 \%)$ & \\
\hline & & Mixed (7.1\%) & \\
\hline
\end{tabular}

manufacturing (62.6\%) and services (14.2\%). It appears that this field has mainly addressed manufacturing sectors (mostly, textile goods at $20.6 \%$ ). On the one hand, this finding is not surprising given the fact that ethical sourcing issues have been traditionally addressed in the more labour-intensive manufacturing industries like textiles. On the other hand, it is interesting that this trend swims against the tide of the generic OSCM research showing the growing importance of service operations. Gupta et al. (2006) found that most of early empirical research published in Production and Operations Management is manufacturing-focused articles; however, this gap has now almost disappeared. While this does not represent the entire trend towards services in the field of OSCM, it suggests an implication for future ethical sourcing research.

The middle columns show the distribution of articles by the disciplines and research methods. First, we classified our 155 sample articles into two major discipline categories, i.e. OSCM and 'other disciplines'. This classification is based on the field of study shown in an author's profile together with the journal's subject area. When the author's profile was not present in the article, we checked the author's official or personal website to identify their disciplinary backgrounds. Overall, we found that OSCM has made the greatest contribution to the literature at $40.6 \%$. Second, to analyse methodological issues, we also classified our sample articles into three broad categories shown in Table 2. It reveals that the majority of ethical sourcing studies are based on qualitative methods (58.4\%), while quantitative methods $(38.1 \%)$ are found to be relatively less popular in this field of study.

We also found an encouraging trend in terms of discipline and methodology. Figure 3 displays the number of articles by discipline for each period. As is shown, the number of OSCM articles has risen rapidly for the recent

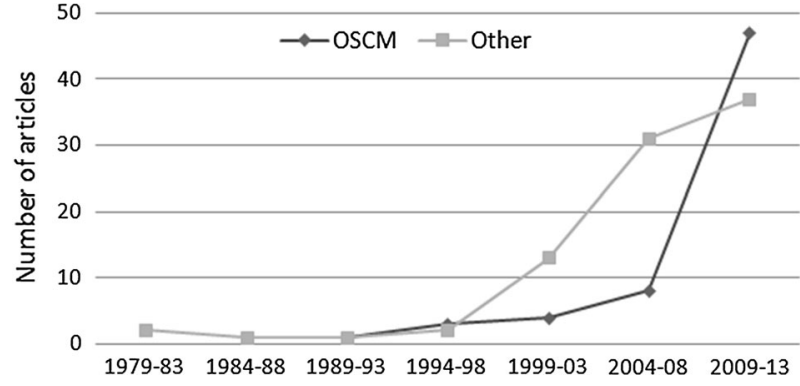

Fig. 3 Number of articles by discipline by time period

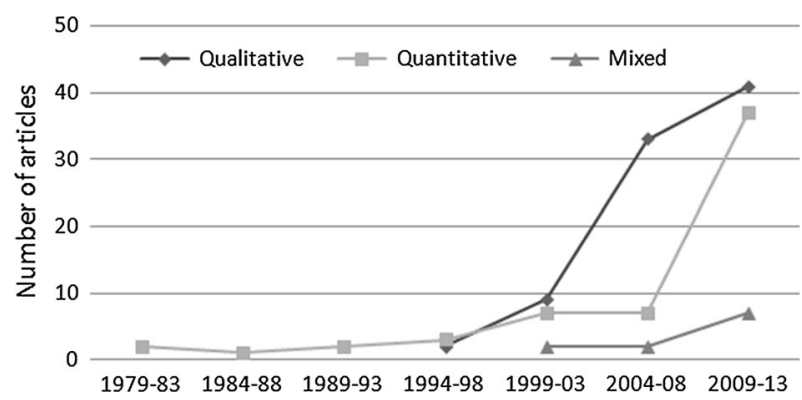

Fig. 4 Number of articles by methodology by time period

time period of 2009-2013, overtaking 'other disciplines'. This means that ethical sourcing has received more attention by OSCM scholars during recent years. Figure 4 illustrates that the gap between the numbers of qualitative and quantitative studies has almost disappeared. The most interesting result is that quantitative methods are becoming popular in the recent time period of 2009-2013.

As noted earlier, we found that qualitative studies are more dominant than quantitative ones in this people-side of sustainability; however, this is not the case when it comes to its green (i.e. planet) counterpart. A recent review on 
Table 3 The most frequently used title words and author keywords

\begin{tabular}{llll}
\hline Title word & Count & Author keyword & Count \\
\hline Supply & 44 & Corporate social responsibility & 35 \\
Ethical/ethics & 42 & Supply chain management & 28 \\
Chain(s) & 40 & Sustainability & 20 \\
Supplier(s) & 32 & Supply chain & 16 \\
Responsible/responsibility & 30 & Codes of conduct & 10 \\
Sustainable/sustainability & 30 & China & 9 \\
Socially/social & 25 & Social responsibility & 9 \\
Global & 22 & Purchasing & 8 \\
Corporate & 21 & Business ethics & 6 \\
Management & 20 & Corporate responsibility & 6 \\
Purchasing & 20 & Ethics & 6 \\
Code(s) & 18 & Labo(u)r standards & 6 \\
Labo(u)r & 17 & Sustainable development & 6 \\
Conduct & 12 & Fair trade & 5 \\
Buyer(s) & 11 & Procurement & 5 \\
Case & 11 & Supply management & 5 \\
\hline
\end{tabular}

green sourcing reveals that quantitative methods (at $67.4 \%$ ) are more prevalent than qualitative approaches $(32.6 \%)$ (Appolloni et al. 2014). Obviously, this is contrary to the current field, in which the majority of studies are based on interpretive approaches. Interpretive approaches like case studies have been used as one of the most powerful methods particularly in building and extending theories (Eisenhardt 1989; Voss et al. 2002; Barratt et al. 2011). In this sense, our findings may indicate that this field of research is still in the early stage of an investigation on the development of new theory. This trend, however, may change in the near future as this area matures especially after 2015 (cf. Fig. 2).

Finally, we found that, of the 155 articles analysed, only $1.9 \%$ of the sample examines whether corporate ethical sourcing is linked to financial performance (e.g. total assets; see the last column of Table 2). Here, we only consider quantitative studies statistically testing the relationship; thus, qualitative-based studies were not included in this analysis. $22.6 \%$ of ethical sourcing articles addressed the impact of ethical sourcing on non-financial performance (e.g. buyer satisfaction). However, the majority of articles $(75.5 \%)$, i.e. mostly qualitative research, are found to be not applicable in this analysis. This means that most of the ethical sourcing articles investigate neither financial nor nonfinancial outcomes in their context, or they do not address the investigated subject in a quantitative way, statistically testing the relationship.

\section{Keyword Statistics}

Table 3 shows the frequency count of the top title words used in ethical sourcing studies published over the last
35 years. 'Supply' appears most often, followed by 'ethical/ethics' and 'chain(s)', which are counted more than 40 times. The words related to 'socially responsible sustainability' also occupy the next three slots. The rest of the title words shown in the table are 'global', 'purchasing', 'code(s)', 'labo(u)r', etc., which represent ethical issues from a sourcing point of view. Table 3 also reports the most often used author keywords in this field. More specifically, the top keywords appeared in the table are 'corporate social responsibility', 'supply chain management', 'sustainability', 'purchasing', etc. It is worth noting that 'codes of conduct' and 'China' are also ranked as the top keywords, indicating their centrality to this field. Overall, the result shown in Table 3 confirms that the search keywords used in this study are strongly aligned with the title words and keywords used by authors in the literature.

\section{Results of Network Analysis}

\section{Citation Network}

The result of a CNA using HistCite is presented in Table 4, showing the 10 most-cited articles within the network. The ranking is based on a local citation score (LCS) that refers to the count of citations to an article from other articles within the dataset. Note that the global citation score (GCS) refers to the count of citations to an article from other articles in the Web of Science. Of 155 articles analysed in this study, 60 articles were not cited by others (i.e. LCS $=0$ ), but it was only 4 articles in the Web of Science (i.e. GCS $=0$ ). The analysis also reveals 
Table 4 The top 10 ranked articles by citation

\begin{tabular}{|c|c|c|c|c|c|}
\hline Rank & Title & Author (year) & Journal & $\mathrm{LCS}^{\mathrm{a}}$ & $\mathrm{GCS}^{\mathrm{b}}$ \\
\hline 1 & $\begin{array}{l}\text { Supply chain specific? Understanding the patchy success of ethical sourcing } \\
\text { initiatives }\end{array}$ & Roberts (2003) & $J B E$ & 29 & 109 \\
\hline 2 & Ethical issues in international buyer-supplier relationships: a dyadic examination & Carter (2000) & $J O M$ & 20 & 80 \\
\hline 3 & $\begin{array}{l}\text { Incorporating sustainability into supply management in the automotive industry - } \\
\text { the case of the Volkswagen AG }\end{array}$ & Koplin et al. (2007) & $J C P$ & 14 & 74 \\
\hline 4 & $\begin{array}{l}\text { Corporate social responsibility in the supply chain: An application in the food } \\
\text { industry }\end{array}$ & Maloni and Brown (2006) & $J B E$ & 13 & 122 \\
\hline 5 & The path to corporate responsibility & Zadek (2004) & $H B R^{\mathrm{c}}$ & 12 & 145 \\
\hline 6 & Corporate social responsibility in global supply chains & $\begin{array}{l}\text { Andersen and Skjoett- } \\
\text { Larsen (2009) }\end{array}$ & $S C M I J$ & 12 & 71 \\
\hline 7 & $\begin{array}{l}\text { Globalization, athletic footwear commodity chains and employment relations in } \\
\text { China }\end{array}$ & Frenkel (2001) & $O S^{\mathrm{d}}$ & 12 & 58 \\
\hline 8 & Social responsibility and supply chain relationships & $\begin{array}{l}\text { Carter and Jennings } \\
(2002)\end{array}$ & $T R E^{\mathrm{e}}$ & 9 & 79 \\
\hline 9 & Compliance, collaboration, and codes of labor practice: The Adidas connection & Frenkel and Scott (2002) & $C M R^{\mathrm{f}}$ & 9 & 53 \\
\hline 10 & $\begin{array}{l}\text { Ethical sourcing codes of large UK-based corporations: Prevalence, content, } \\
\text { limitations }\end{array}$ & Preuss (2009) & $J B E$ & 9 & 25 \\
\hline
\end{tabular}

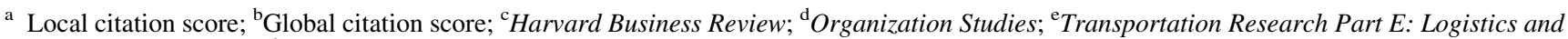
Transportation Review; ${ }^{\mathrm{f}}$ California Management Review

Table 5 The top 10 ranked articles by centrality

\begin{tabular}{|c|c|c|c|c|}
\hline Rank & Title & Author (year) & Journal & $\mathrm{CCS}^{\mathrm{a}}$ \\
\hline 1 & Corporate social responsibility in the supply chain: An application in the food industry & $\begin{array}{l}\text { Maloni and Brown } \\
\text { (2006) }\end{array}$ & $J B E$ & 0.4138 \\
\hline 2 & Supply chain specific? Understanding the patchy success of ethical sourcing initiatives & Roberts (2003) & $J B E$ & 0.4044 \\
\hline 3 & $\begin{array}{l}\text { Incorporating sustainability into supply management in the automotive industry-the case } \\
\text { of the Volkswagen AG }\end{array}$ & Koplin et al. (2007) & $J C P$ & 0.3819 \\
\hline 3 & $\begin{array}{l}\text { Sustainable purchasing and supply management: a structured literature review of definitions } \\
\text { and measures at the dyad, chain and network levels }\end{array}$ & Miemczyk et al. (2012) & SCMIJ & 0.3819 \\
\hline 5 & $\begin{array}{l}\text { An empirical examination of the relationship between business strategy and socially } \\
\text { responsible supply chain management }\end{array}$ & Hoejmose et al. (2013) & $I J O P M$ & 0.3796 \\
\hline 6 & Ethical climate and purchasing social responsibility: a benevolence focus & $\begin{array}{l}\text { Blome and Paulraj } \\
\text { (2013) }\end{array}$ & $J B E$ & 0.3750 \\
\hline 7 & Corporate social responsibility in global supply chains & $\begin{array}{l}\text { Andersen and Skjoett- } \\
\text { Larsen (2009) }\end{array}$ & $S C M I J$ & 0.3705 \\
\hline 8 & Ethical issues in international buyer-supplier relationships: a dyadic examination & Carter $(2000)$ & $J O M$ & 0.3694 \\
\hline 8 & $\begin{array}{l}\text { Socially and environmentally responsible procurement: a literature review and future } \\
\text { research agenda of a managerial issue in the } 21 \text { st century }\end{array}$ & $\begin{array}{l}\text { Hoejmose and Adrien- } \\
\text { Kirby (2012) }\end{array}$ & $J P S M^{\mathrm{b}}$ & 0.3694 \\
\hline 10 & Ethical sourcing codes of large UK-based corporations: prevalence, content, limitations & Preuss (2009) & $J B E$ & 0.3495 \\
\hline
\end{tabular}

${ }^{\mathrm{a}}$ Closeness centrality score; ${ }^{\mathrm{b}}$ Journal of Purchasing and Supply Management

that the GCS is significantly higher than the LCS. This gap may indicate that the topic of ethical sourcing has also drawn much attention from outside the scope of this study.

Table 5 also shows the top 10 ranked articles by a closeness centrality score (CCS) that is measured using Pajek. The CCS refers to the average distance of a given node from all other nodes, reflecting the extent to which the node is central to its network. Mathematically, the CCS can be represented by $C_{\mathrm{CS}}(i)=n-1 / \sum_{j=1}^{n} d(i, j)$, where $n$ is the number of nodes; $d(i, j)$ is the number of links in the shortest path (i.e. distance) from node $i$ to node $j$ in the network (Sabidussi 1966). The result reveals that the top 6 cited articles are also ranked with highest CCSs, suggesting a positive relationship between the two approaches. Further, 4 articles appear to be new to Table 5 , all of which 


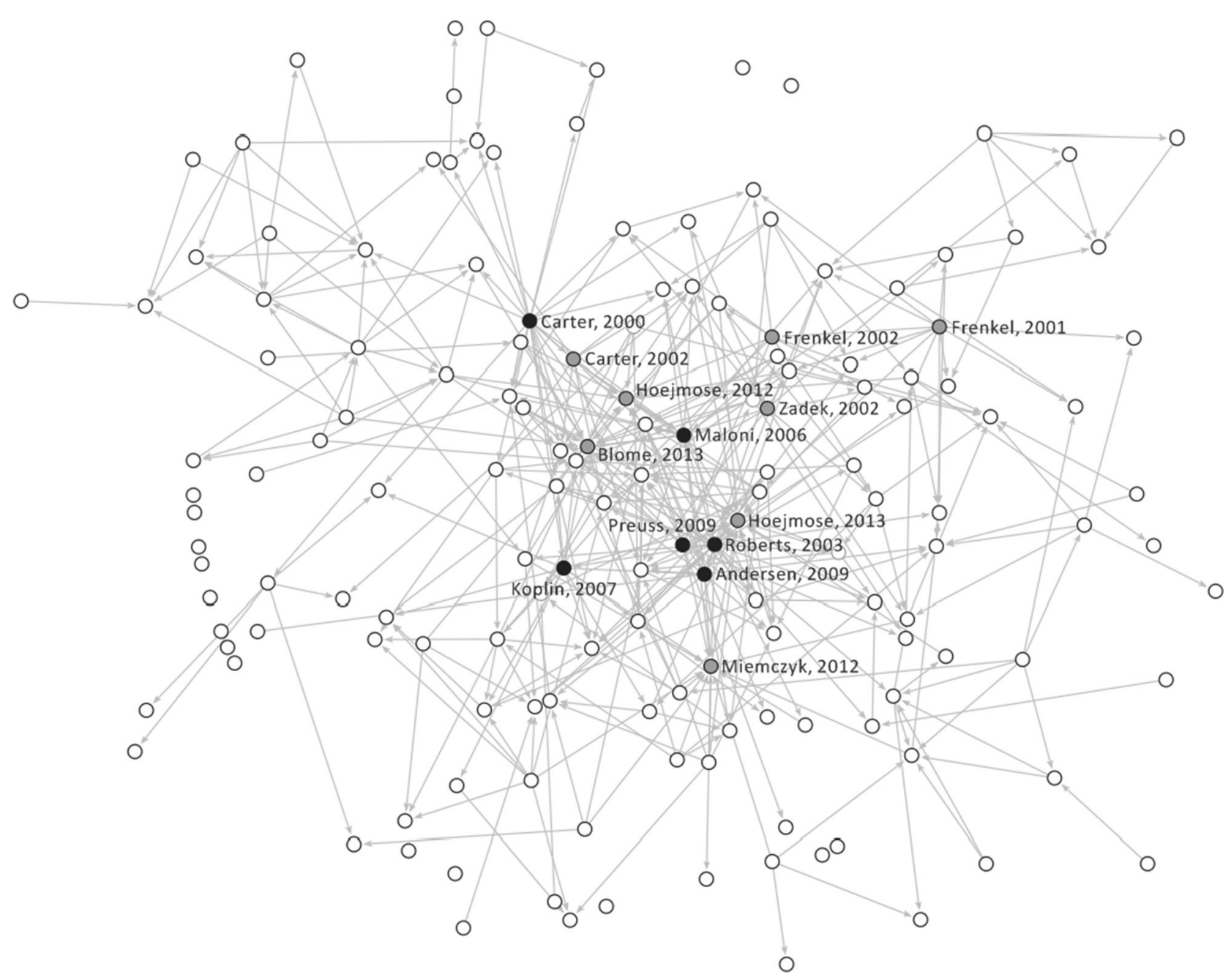

Fig. 5 Citation network and the top ranked articles

have been published in recent years. In fact, that recent articles are not likely to appear in Table 4 , as they may not have had sufficient time to be cited. In this respect, we believe that the CCS could complement the citation approach (i.e. LCS and GSC).

Figure 5 visually illustrates the citation network of 155 nodes and the top ranked articles identified above. The black nodes shown in the figure indicate the top 10 articles ranked by both citation and centrality (i.e. 6 articles shown in both Tables 4,5 ), while the grey nodes represent the remaining articles ranked by either citation or centrality among the top ten. Overall, this shows the knowledge structure of ethical sourcing research, establishing a baseline for identifying the evolution of ethical sourcing thought. The positioning of these articles in the network also shows how central they are in this area of research. Therefore, reviewing these influential articles could be a starting point for those interested in this topic.

\section{Main Path}

Figure 6 illustrates the main path of the development of ethical sourcing studies for the last 35 years (1979-2013). The main path consists of 15 articles that play a major role in the development of this field, which are labelled with the first author's surname and publication year. There are two sources (Browning and Zabriskie 1983; Rudelius and Buchholz 1979) and 5 sinks (Gimenez and Tachizawa 2012; Hoejmose et al. 2013; Lee et al. 2013; Reimann et al. 2012; Reuter et al. 2012). They are depicted as black and blank nodes, respectively. Overall, these articles provide a mapping of the main path regarding development trajectories in this field of research, showing the process of knowledge creation and its transfer. This map thus exhibits how this area has evolved over the decades, giving a sense of its future.

The two source articles have examined the ethical problems of purchasing management (e.g. bribery). Their 


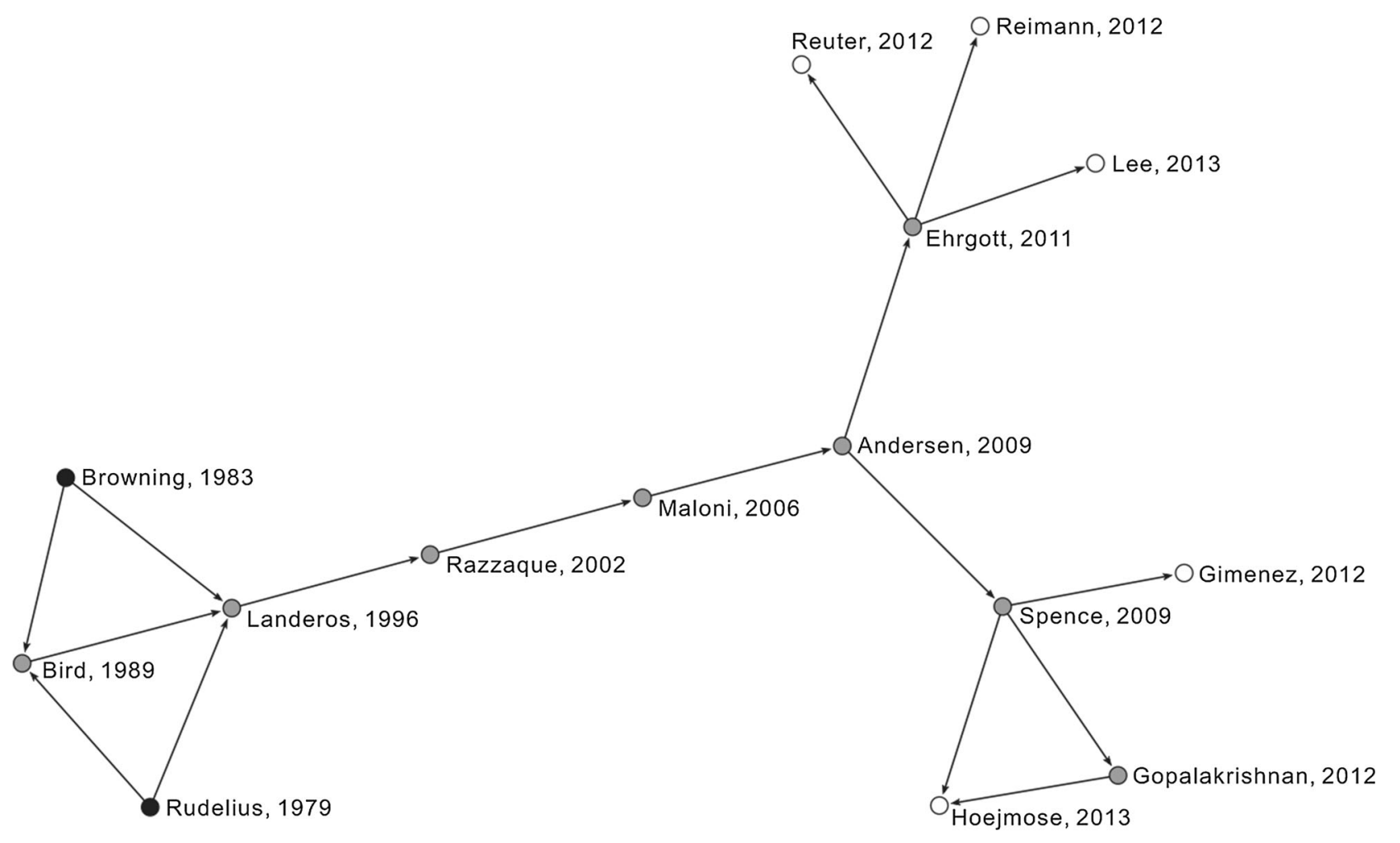

Fig. 6 Main path of ethical sourcing studies

main focus is to measure how ethical buyers are in their relationship with suppliers. Both studies have found that purchasing managers have a high level of ethical belief, but some of them (e.g. older managers) still have a tendency to view such questionable practices as a part of business dealings. Following on, other early studies by Bird (1989) and Landeros and Plank (1996) have also focused on the same topic, investigating the ethical behaviour of industrial purchasers. The results they found are generally consistent with findings by prior studies, indicating that purchasing managers appear to have high level of ethical behaviour.

It is worth noting that up until then the target respondents of the above works were only US purchasing managers. In the more recent study, however, Razzaque and Hwee (2002) explored its ethical beliefs from the Singaporean view and found slightly different results (i.e. gender issues). Similar articles are found in our sample but do not appear on the main path, which also examine perceptual differences across countries. Examples of these studies are Motwani et al. (1998), Tadepalli et al. (1999) and Ford et al. (2000), who focused on India, Mexico, and Japan, respectively. Overall, they found that purchasing managers in those countries are less ethical than their US counterparts because of the culture they have fostered in different ways. To summarise, at this stage of the literature (1979-2002), the focus of research was unethical purchasing behaviour, and it seems that this research trend began to spread all over the globe. However, their scope was only limited to the internal or dyadic (i.e. buyer-supplier) environment, thus failing to deal with the ethical issue from the view of extended purchasing operations, i.e. supply chain management.

This early approach has been further developed by the evolution integrating the corporate social responsibility (CSR) concept into sourcing operations. This trend has been largely triggered by a series of breakdowns in corporate supply chains (e.g. Nike's child labour) that have attracted great attention from the public. The first leading article on this development path is by Maloni and Brown (2006). Given the importance of CSR issues (e.g. sweatshop) in the food supply chain, the authors proposed an integrated framework consisting of eight broad categories: procurement, fair trade, health and safety, labour and human rights, animal welfare, biotechnology, environment, and community. In fact, the idea for this conceptual framework is based on prior ethics and CSR research, especially on the concept of purchasing social responsibility (PSR). Carter and Jennings (2002) define PSR as the involvement of the purchasing manager in CSR activities such as human rights and philanthropy. Despite its absence on the main path, we believe their contribution is also crucial in terms of explaining the infusion of CSR issues into purchasing and supply management. 
Another leading article at this stage is by Andersen and Skoett-Larsen (2009), mainly influenced by Maloni and Brown's (2006) discussion. Using a case study methodology, the authors examined how the Swedish retail firm, IKEA, manages CSR practices at its suppliers (e.g. employee training and sharing of experience). Their contribution is crucial in the development of this knowledge path, especially in the way that they delve into how CSR practices are embedded within the (IKEA) supply chain. Other similar articles are found at this time in the literature but are not shown on the main path (Amaeshi et al. 2008; Boyd et al. 2007); both of them have also introduced CSR issues in supply chains, thus contributing to the development of ethical sourcing theory. Overall, articles in this period reflect scholarly attempts to discuss the incorporation of CSR issues into the supply chain context. It is also beyond the earlier scope of the internal or dyadic issues. However, it appears that the focus of these studies is largely limited to the focal firm with CSR applications. This means that these early studies have failed to define the adequate level of ethical and social responsibility for a complicated supply chain.

Following Andersen and Skoett-Larsen (2009), as shown in Fig. 6, the main path has been split into two separate paths. We found that articles on the lower path mainly discuss how to deploy social responsibility into suppliers, while articles on the upper path are focused on challenges of supplier management in emerging countries. A set of articles on each path clearly reflects emerging trends in recent ethical sourcing studies, which we describe next.

\section{Incorporating Ethical and Social Responsibility into Suppliers}

This path begins with the article by Spence and Bourlakis (2009) which examines the evolution from CSR to what they call 'supply chain responsibility (SCR)'. SCR is the concept that goes beyond CSR to capture the necessary level of social sustainability for the entire supply chain. While the focus of prior studies like Maloni and Brown (2006) is the infusion of CSR issues into a supply chain, the authors advance this early, broad approach by shifting its focus to SCR, thus providing a better understanding of social responsibility that fitted into a supply chain context. It should be noted that their theoretical background is in line with that of the work by Eltantawy et al. (2009). Somewhat similarly, Eltantawy et al. (2009) also extend the concept of CSR to define 'supply management ethical responsibility' as a determinant of supply management performance. Overall, these studies on this development path have caused a paradigm shift in this field.
In addition to defining SCR, another contribution made by Spence and Bourlakis (2009) is their empirical findings regarding extended responsibility in a supply chain. Based on a case study carried out at Waitrose, a UK food retailer, and its suppliers, the authors argue that achieving SCR requires that managerial activity should be expanded into suppliers. Examples of such activity are supplier ethical audits, responsible sourcing code of practice and managing supplier relationships. Following them, a series of articles have addressed similar issues. Gimenez and Tachizawa (2012) conduct a systematic review on this issue, providing a conceptual framework of extending SCR to suppliers. Gopalakrishnan et al. (2012) use a case study analysis to investigate best practice guides for the deployment of SCR in its suppliers. Taking a slightly different view, Hoejmose et al. (2013) examine the impact of business strategy (e.g. differentiation strategy) on socially responsible supply chain management. The authors have explored how to support suppliers to be more socially responsible through the particular strategy. Generally speaking, articles on this path have recently begun to consider facilitating the extension of ethical and social responsibility at suppliers, representing an emerging trend in this field of research.

\section{Stakeholders and Supplier Management in Emerging Countries}

The leading article on this path is the contribution by Ehrgott et al. (2011). The major aim of this study is to examine how stakeholder pressures determine the extent to which focal firms consider ethical and social aspects in selecting suppliers in emerging countries. The authors regard pressures from numerous stakeholders (e.g. customers) as antecedents of socially responsible supplier selection and then verify these hypothetical relationships using structural equation modelling. Following them, a series of articles have emerged on this path, focusing on the influence of stakeholder power on supplier management in developing countries. Reimann et al. (2012) examine the role of corporate social strategies (e.g. working conditions) in emerging countries. Building on stakeholder theory, i.e. according to which a success of a firm depends on their relationships with other internal and external actors involved, the authors investigate how such social strategies are affected by local stakeholders. In the same vein, Reuter et al. (2012) examine the causal relationship between firm's orientation towards certain stakeholders and their social responsibility in supplier selection decisions. Lee et al. (2013) analyse the effect of employee rights protection on corporate financial performance. By using the stakeholder approach, the authors theoretically explain how worker rights protection can lead to financial performance of Chinese manufacturers. 


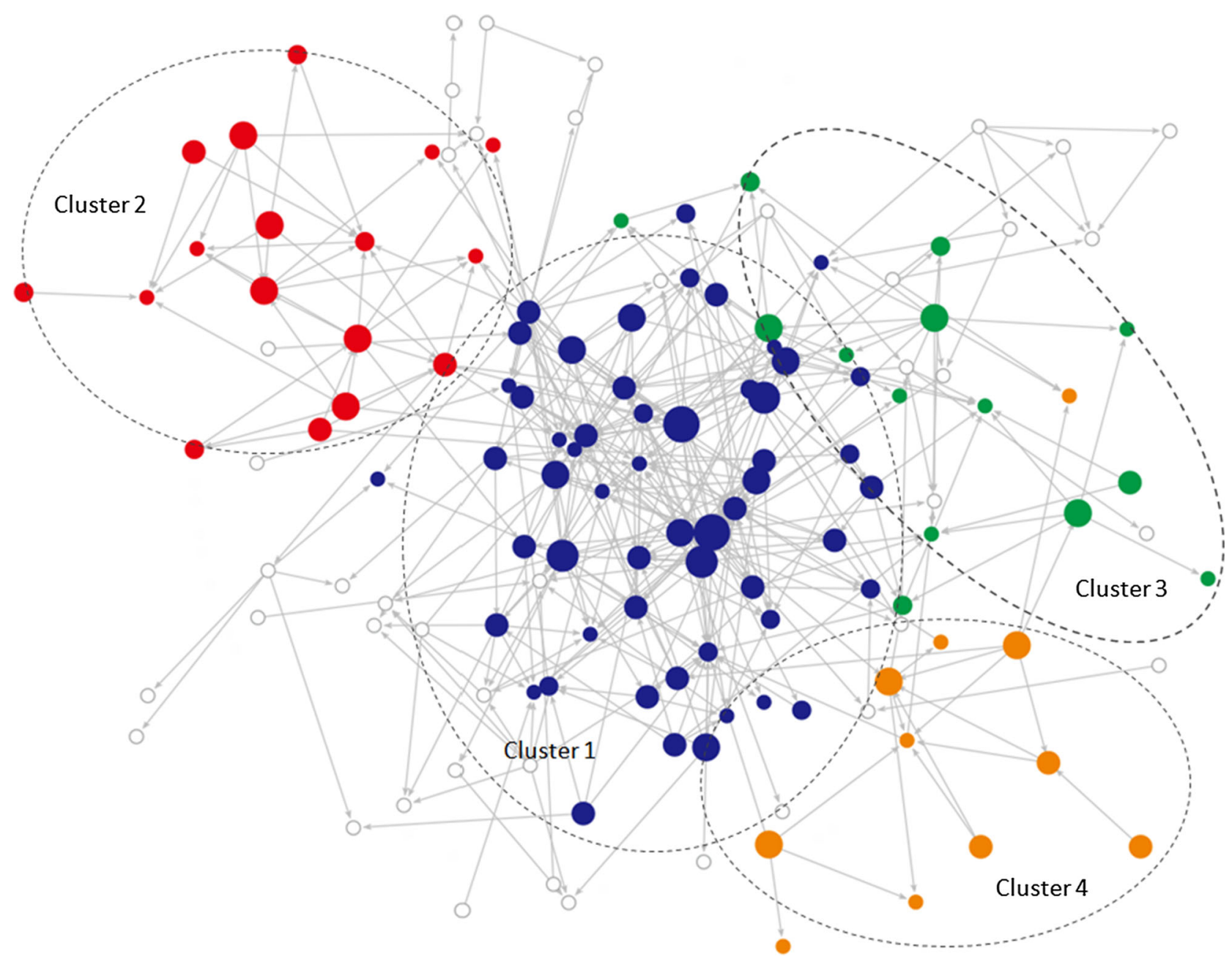

Fig. 7 The four major clusters in citation network (excluding isolated nodes)

In short, the focus of research on this development path is not on the focal firm with CSR applications anymore. Rather, most of them take a broader view considering not only vertical (e.g. suppliers and customers) but also horizontal (e.g. the government and the community) actors in a supply chain, extending its analysis level to a wider network of the supply chain. These studies are focused mainly on the issue beyond corporate boundaries exploring how stakeholders outside the focal firm determine sourcing operations in emerging countries and how to address these issues for future development.

\section{Data Clustering}

To further identify the topical structure of the network, we conduct a cluster analysis using Girvan-Newman algorithm. The 155 nodes of a network are divided into 23 clusters with the $Q$-value of 0.355 that falls in the normal range of 0.3-0.7. Among them, we chose 4 major clusters to analyse in this study because the other clusters contain only $2-5$ articles that have little or no relevance to each other. The major 4 clusters consist of 97 articles all together, which account for $62.5 \%$ of the total sample. The mapping of four clusters is visually illustrated in Fig. 7, where the size of the node is proportional to the number of citations within each cluster. Such classification clearly shows the topical structure of existing ethical sourcing studies, thus providing more insights into this field of research.

A summary of the analysis result is presented in Table 6. Specifically, Cluster 1 is the largest cluster consisting of 55 articles, which is labelled as socially responsible supply management. This cluster includes articles focusing on buyer's efforts to take into account ethical criteria when managing current and potential suppliers. Broadly speaking, articles in this cluster can be described in the following two aspects: selection and monitoring. It has become a key priority for many firms to select the most appropriate supplier while achieving sustainability goals. Its aim is to choose only suppliers who 
Table 6 Summary of the four major clusters $(Q=0.355)$

\begin{tabular}{|c|c|c|c|}
\hline Cluster & Research area & $\begin{array}{l}\text { No. of } \\
\text { articles }\end{array}$ & Description \\
\hline 1 & $\begin{array}{l}\text { Socially responsible } \\
\text { supply management }\end{array}$ & 55 & $\begin{array}{l}\text { These studies focus on socially responsible issues in supply management (e.g. human rights } \\
\text { and occupational safety), especially on how to infuse ethical and social considerations into } \\
\text { supply chains }\end{array}$ \\
\hline 2 & $\begin{array}{l}\text { Unethical purchasing } \\
\text { behaviour }\end{array}$ & 17 & $\begin{array}{l}\text { Studies that look at ethical problems of purchasing managers (e.g. bribery and corruption) } \\
\text { both within and between organisations }\end{array}$ \\
\hline 3 & $\begin{array}{l}\text { Ethical sourcing codes of } \\
\text { conduct }\end{array}$ & 14 & $\begin{array}{l}\text { Articles that explore the benefits (e.g. improving labour rights in a supply chain) and } \\
\text { limitations (e.g. limited in application) of adopting ethical sourcing codes of conduct }\end{array}$ \\
\hline 4 & Fair and ethical trade & 11 & $\begin{array}{l}\text { Research examining the economic impact of fair and ethical trade on developing countries, } \\
\text { which have contributed to building a better world }\end{array}$ \\
\hline
\end{tabular}

best meet the ethical criteria (e.g. no sweatshop). Meanwhile, monitoring pertains to those buyer's practices associated with the regular assessment of current supplies (e.g. auditing). Formal monitoring can help uncover deficits of suppliers at an early stage. In particular, it can provide a buyer with capabilities that a competitor would be unable to copy quickly (Foerstl et al. 2010; Reuter et al. 2010), while preventing their brand image tarnished by suppliers' misconduct (Awaysheh and Klassen 2010; Klassen and Vereecke 2012). However, such monitoring does not lead to greater supplier compliance (Boyd et al. 2007; Baden et al. 2009; Lim and Phillips 2008; Jiang 2009). Monitoring has been seen as a beneficial tool for inducing improvement in supplier management; yet, most researchers seem to agree that its arms-length approach cannot fully control supplier compliance.

Cluster 2 contains 17 articles, all of which are focused on questionable practices conducted by purchasing managers. This cluster is thus labelled as unethical purchasing behaviour, which is thus in line with the early research stream of the main path. There are many forms of unethical purchasing behaviour; some of these may include giftgiving/taking, accepting a bribe, padding expense accounts, coercive or opportunistic behaviour, and preferential treatment for certain suppliers. (Rudelius and Buchholz 1979; Browning and Zabriskie 1983; Bird 1989; Rotting et al. 2011). Many scholarly efforts have been made to categorise this issue; for example, based on whether or not these are explicitly or implicitly prohibited in the firm, Saini (2010) divides such behaviour into three different aspects: explicitly prohibited by corporate policy (e.g. gifts), implicitly/normatively prohibited in the firm (e.g. coercion), and no explicit or implicit policy (e.g. opportunism). Since such misbehaviour can cause a negative effect on the buyer-supplier relationship, several articles in this cluster have also discussed how to address its negative consequences (e.g. Gonzalez-Padron et al. 2008; Hawkins et al. 2013). Broadly speaking, it seems that enhancing ethical culture (e.g. top management support) has been regarded as the most effective way of not only preventing such questionable issues but also promoting ethical behaviour in supply management.

Cluster 3 is composed of 14 articles examining codes of conduct in ethical sourcing. We thus label this cluster as ethical sourcing codes of conduct. Many giant firms are now coming under ever-increasing pressure from various stakeholders to participate in ethical and social practices (e.g. no sweatshop). In such situations, a corporate code of conduct is a voluntary initiative that stipulates CSR towards its stakeholders. That is, by creating such a voluntary code of conduct, a firm can give the appearance of conformity, thus meeting stakeholder expectations. Corporate codes of conduct have been regarded as one of the effective tools for managing CSR (Roberts 2003; Preuss 2009); however, there is a critique of its effectiveness (Frenkel 2001; Locke and Romis 2010; Taylor 2011; Knudsen 2013). As stated by Frenkel and Scott (2002), pp. 30-31, "voluntary codes are restricted to a relatively small number of global firms and they only regulate firsttier exporters in particular sectors in developing countries". As such, it has a certain limitation in which a corporate code of conduct alone is insufficient to extend a firm's ethical responsibilities across the supply chain.

Cluster 4 consists of 11 articles, and it is the smallest major cluster in the network. These articles focus mainly on fair and ethical trade in global business and thus are labelled as fair and ethical trade. The current fair trade scheme has its roots in the 1950-1960s when Alternative Trade Organizations (ATOs) conducted a number of social activities such as Oxfam Trading. The main purpose of such activities was to create alternative trading channels between southern producers and northern consumers, thus helping producers in developing countries (Browne et al. 2000; Robinson 2009). In this sense, the fair trade movement thus describes itself as a response to the failure of conventional trade to alleviate social inequalities resulting 
Table 7 Summary of the content issues of each cluster

\begin{tabular}{lllll}
\hline Content issue & Cluster 1 (\%) & Cluster 2 (\%) & Cluster 3 (\%) & Cluster 4 (\%) \\
\hline Industry sector & & & & \\
Manufacturing & 67.3 & 47.1 & 85.8 & 45.5 \\
Services & 10.9 & 5.8 & 7.1 & 45.5 \\
None & 21.8 & 47.1 & 7.1 & 9.0 \\
Discipline base & & & & \\
OSCM & 67.3 & 35.3 & 14.3 & 9.1 \\
Other disciplines & 32.7 & 64.7 & 85.7 & 90.9 \\
Research method & & & & \\
Qualitative & 58.2 & 11.7 & 85.7 & NA \\
Quantitative & 32.7 & 76.4 & 14.3 & NA \\
Mixed & 9.1 & 11.7 & NA & \\
Performance issue & & & & NA \\
Non-financial & 25.4 & 17.7 & 7.1 & NA \\
Financial & 1.8 & NA & NA & 100.0 \\
Not-applicable & 72.8 & 82.3 & 92.9 & \\
\hline
\end{tabular}

from it. On the other hand, ethical trade emerged from individual firms in the 1990s when they were accused of producing consumer goods in sweatshops. The trend towards ethical trade has evolved rapidly over the last decades. This was further reinforced by the formation of ATOs' umbrella organisation: the Ethical Trading Initiative (ETI) (Blowfield 1999; Hughes 2005; Hughes et al. 2007). The ETI was established in 1998 by a group of large firms, NGOs, and trade union in the UK. Its major aim is to establish a baseline code for corporations. Taken together, fair trade seeks the justice of foreign trade between producers and buyers, while ethical trade is mainly concerned with the improvement of working conditions in the shop floor. Although these two concepts are slightly different, both approaches aim at enhancing the livelihood of disadvantaged workers in developing countries.

Table 7 provides a summary of the content issues of each cluster, which is analysed by using the same structure applied earlier. For the industry sector, Cluster 1 presents results most similar to the entire field of research, with manufacturing-focused articles at $67.3 \%$. Nearly half of the articles in Cluster 2 are classified into the 'None' category. This is because articles in this category were published without explaining the industrial background. It is also worth noting that Cluster 3 is dominated by the manufacturing sector $(85.8 \%)$, indicating that service research in this area is relatively neglected. In terms of the discipline base, Cluster 1 is more contributed by OSCM. The other clusters, on the other hand, are dominated by other disciplines. Generally speaking, articles in each cluster are more based on qualitative methods than quantitative ones. However, quantitative research is found to be more popular in Cluster 2, of which all studies are based on survey. Finally, performance issues have been rarely addressed in any cluster, albeit slightly higher in Cluster 1 when compared with the other clusters.

Table 8 shows a summary of the most popular title words and author keywords used in each cluster. As shown, the title words and keywords appeared in the table are in line with the naming of each cluster discussed earlier. It is also interesting that the words 'codes' and 'China' are both from Cluster 3, i.e. ethical sourcing codes of conduct. It appears that labour standards in China have been widely discussed in this research area. Table 9 illustrates the top 3 ranked articles within each cluster, which are measured by LCS. Some leading articles (e.g. Frenkel 2001) appear to be new in the tables when compared to those for the entire literature (cf. Tables 2, 3, 4, 5). These studies play a central role in each research domain, giving a starting point for those who are interested in this topic. Overall, these results provide detailed features of each cluster, thus advancing our understanding in this field of ethical sourcing research.

\section{Implications for Future Research}

The results of this study have provided some implications for future ethical sourcing research. In the following narrative, therefore, this study will highlight ten major implications (summarised in Table 10) that need to be pursued by future interested researchers.

First, research on ethical sourcing issues in services is relatively under examined. As noted earlier, the sample articles analysed in this study are focused more on manufacturing, such as textile goods. This result is not surprising as ethical sourcing issues such as child labour and sweatshop generally occur to such a more labour-intensive industry. However, it should be noted that child labour 
Table 8 Summary of the most popular keywords of each cluster
Table 9 Summary of the top ranked articles within each cluster

\begin{tabular}{llllc}
\hline Cluster & Title word & Count & Author keyword & Count \\
\hline 1 & Supply & 29 & Corporate social responsibility & 23 \\
& Chain & 26 & Supply chain management & 19 \\
& Responsible/Responsibility & 20 & Sustainability & 11 \\
2 & Ethical/Ethics & 13 & Business ethics & 2 \\
& Purchasing & 10 & Ethics & 2 \\
& Behavior & 3 & Procurement & 2 \\
& Chain(s) & 6 & Labo(u)r standards & 4 \\
& Global & 6 & Corporate social responsibility & 4 \\
& Codes & 5 & China & 3 \\
& Ethical & 8 & Ethical trade & 3 \\
& Trade & 6 & Corporate responsibility & 2 \\
& Corporate & 3 & Fair trade & 1 \\
\hline
\end{tabular}

\begin{tabular}{lllll}
\hline Cluster & Author (year) & LCS (GCS) & Author (year) & CCS \\
\hline 1 & Roberts (2003) & $23(112)$ & Roberts (2003) & 0.6166 \\
& Carter (2000) & $12(81)$ & Hoejmose et al. (2013) & 0.6166 \\
& Maloni and Brown (2006) & $12(124)$ & Maloni and Brown (2006) & 0.5764 \\
& Landeros and Plank (1996) & $6(16)$ & Landeros and Plank (1996) & 0.6666 \\
& Browning and Zabriskie (1983) & $5(60)$ & Robertson and Rymon (2001) & 0.6400 \\
& Robertson and Rymon (2001) & $4(29)$ & Rotting et al. (2011) & 0.6153 \\
& Frenkel (2001) & $6(58)$ & Frenkel (2001) & 0.5416 \\
& Barrientos and Smith (2007) & $5(74)$ & Taylor (2011) & 0.5000 \\
& Frenkel and Scott (2002) & $4(54)$ & Barrientos and Smith (2007) & 0.4814 \\
& Blowfield (1999) & $4(49)$ & Hughes (2005) & 0.6111 \\
& Hughes (2005) & $3(28)$ & Hughes et al. (2007) & 0.6111 \\
& Smith and Barrientos (2005) & $3(35)$ & Blowfield (1999) & 0.5392
\end{tabular}

Table 10 Identifying research directions in ethical sourcing research

\begin{tabular}{|c|c|c|}
\hline Category & Gap/issue & Research direction \\
\hline Industry sector & $\begin{array}{l}\text { Focus primarily on } \\
\text { manufacturing }\end{array}$ & $\begin{array}{l}\text { Investigating the ethical and socially responsible issues that often occur in service sectors as } \\
\text { well such as logistics services }\end{array}$ \\
\hline $\begin{array}{l}\text { Performance } \\
\text { outcome }\end{array}$ & $\begin{array}{l}\text { Less known about financial } \\
\text { impact }\end{array}$ & $\begin{array}{l}\text { Examining whether ethical and social issues in sourcing operations are positively/negatively } \\
\text { linked to financial performance }\end{array}$ \\
\hline $\begin{array}{r}\text { Research } \\
\text { method }\end{array}$ & $\begin{array}{l}\text { Dominated by either case } \\
\text { study or survey }\end{array}$ & $\begin{array}{l}\text { Employing more alternative methods using secondary data sources, e.g. database research, in } \\
\text { order to generalise related results }\end{array}$ \\
\hline $\begin{array}{l}\text { Geographic } \\
\text { aspect }\end{array}$ & $\begin{array}{l}\text { Comparison of issues } \\
\text { between countries }\end{array}$ & $\begin{array}{l}\text { Exploring geographic aspects by focusing on the comparison between home and host country's } \\
\text { views of ethical sourcing }\end{array}$ \\
\hline Unit of analysis & $\begin{array}{l}\text { Focus traditionally on firm/ } \\
\text { dyadic levels }\end{array}$ & $\begin{array}{l}\text { Extending research focus into network levels, considering not only vertical players but also } \\
\text { horizontal actors in the supply chain }\end{array}$ \\
\hline $\begin{array}{l}\text { Up- versus } \\
\text { downstream }\end{array}$ & $\begin{array}{l}\text { Where more unethical } \\
\text { issues take place }\end{array}$ & $\begin{array}{l}\text { Investigating whether ethical issues predominately take place in upstream suppliers or in } \\
\text { downstream retailers, and which party instigates the behaviour }\end{array}$ \\
\hline Ethical mindset & $\begin{array}{l}\text { Likelihood of future ethical } \\
\text { concerns }\end{array}$ & $\begin{array}{l}\text { Determining if learning from ethical situations leads firms to be more ethically responsible, } \\
\text { lowering the likelihood of future concerns }\end{array}$ \\
\hline $\begin{array}{l}\text { Codes of } \\
\text { conduct }\end{array}$ & $\begin{array}{l}\text { Limited application in the } \\
\text { supply chain }\end{array}$ & $\begin{array}{l}\text { Analysing how to enhance greater supplier compliance with buyer's ethical codes of conduct } \\
\text { through collaborative relationships }\end{array}$ \\
\hline $\begin{array}{l}\text { Social } \\
\text { movements }\end{array}$ & $\begin{array}{l}\text { Disparate findings on its } \\
\text { economic impact }\end{array}$ & $\begin{array}{l}\text { Conducting a comprehensive investigation on such a gap using systematic methods such as } \\
\text { meta-analysis }\end{array}$ \\
\hline Discipline base & $\begin{array}{l}\text { Lack of OSCM's point of } \\
\text { view }\end{array}$ & $\begin{array}{l}\text { Examining the fair and ethical trade schemes from an OSCM point of view, thus integrating } \\
\text { both theories. }\end{array}$ \\
\hline
\end{tabular}


aged between 7 and 14 is actually employed more widely in service sectors in most of the emerging countries (World Bank 2015). In Mexico, for example, the 2011 survey shows that the employment rate of children in service sectors accounts for more than $50 \%$, which is five times larger than that of the manufacturing sector $(9.5 \%)$. This statement clearly indicates that ethical and social issues in services should also not be underestimated in this field of research.

An example of ethical sourcing issues in service operations would include call centre sweatshops. Recently, T-mobile's call centres, which is a division of the German telecommunications firm operating in the USA, are alleged to force their employees to work in sweatshop-like conditions with low pay and long hours (People's World 2013). The hunger strike by Chilean Starbucks workers could be another example of ethical issues in service sourcing. In 2011, over 200 baristas working in the 30 Starbucks in Chile went on strike in protest at their low wages (Jargon 2011). Obviously, these examples have proven to be controversial in many different aspects but clearly are corporate scandals involving allegations of sweatshop issues in modern business. Overall, it can be stated that the importance of service sectors in terms of ethical sourcing has been relatively ignored. Therefore, we believe that there is a great potential for addressing these sectors in future ethical sourcing studies.

Second, testing the financial effect of ethical sourcing is often neglected, although this aspect has been discussed in qualitative-based studies. In this study, we found that only 3 articles have statistically analysed whether there is a causal link between ethical sourcing and financial performance (Gallear et al. 2012; Hollos et al. 2012; Lee et al. 2013). We note that Carter (2005) also addresses this issue; however, it was not included in our analysis as its journal was not covered by the Web of Science at the time of publication. Even so, it is clear that research into this aspect has been largely overlooked. On the one hand, this is a very surprising result when considering the literature that has developed over the decades. On the other hand, this result clearly supports our earlier statement that ethical sourcing studies are still in the early stage focusing more on developing new theory. In fact, some of the prior studies are focused on the consequences of corporate ethical sourcing, including buyer satisfaction (Akamp and Müller 2013; Carter 2000; Kaynak and Sert 2012), supplier performance like capabilities (Carter and Jennings 2002; Ehrgott et al. 2011), buyer reputation (Eltantawy et al. 2009), relationship performance (Gonzalez-Padron et al. 2008; Leonidou et al. 2013), and supplier compliance (Jiang 2009). However, it is only lately that authors have begun to direct attention towards the financial effects of ethical sourcing.
Third, it should be noted that all these three articles without exception are based on surveys. One problem with this is the possibility of social desirability response (SDR) bias, which can occur in data collection as its research subjects are associated with business ethics (Randall and Fernandes 1991). The SDR bias refers to "the tendency of individuals to present themselves favourably with respect to current social norms and standards" (Zerbe and Paulhus 1987). In this sense, survey respondents or interviewees would respond to questions about their ethical matters in an overly positive way, thus potentially causing the bias. For this reason, we believe that information about the financial impact of ethical sourcing collected through human participants would not be as reliable and objective as secondary data, unless the SDR bias can be successfully managed. Therefore, as well as surveys or case studies, future research needs to consider more alternative methods using secondary data sources, such as event study methodology, for the financial analysis of ethical sourcing.

Fourth, research on geographic aspects has been less explored. This study provides distinctive features of ethical sourcing studies from various points of view. Despite this, however, the current study fails to address if any one country or region is more/less ethical than another when it comes to supply chain issues. In fact, some prior studies have been done regarding this aspect, but are limited to purchasing managers (e.g. Razzaqque and Hwee 2002) as we discussed in the main path. It is thus timely to explore this, given the fact that firms bring up ethical issues in supply management around the globe. Future studies could address this issue by focusing on the comparison between home and host country's views of ethical sourcing. It may also be worthwhile to examine if there are cultural gaps between countries in terms of addressing ethical issues in supply chains.

Fifth, much of the past research in this area had focused only on ethical issues on the internal and dyadic levels (i.e. within the supply chain). However, there is an increased need for further research on the network levels of analysis (i.e. outside the supply chain). We found through the main path analysis that this field has evolved for decades to consider other supply chain stakeholders such as the government and NGOs. This is a very encouraging trend for future investigations as ethical sourcing has been traditionally focused upon the internal, dyadic or supply chain environment. From the analysis, we also found that scholars in recent research have paid attention to incorporating the ethical responsibility of focal firms into supply management. Taken together, these findings suggest that future research needs to take a broader view beyond the dyadic/chain level when it comes to investigating ethical matters in supply management. It should be able to address outside pressures from numerous stakeholders, while at the 
same time examining how such ethical issues can be effectively managed in upstream supply chains.

Sixth, less is known about how to enhance supplier's compliance with buyer's ethical sourcing policies. As discussed earlier, it has been known that corporate ethical sourcing codes of conduct (or monitoring) are a major source of responding to ethical challenges imposed by global sourcing. However, it is apparent from the literature that these codes are limited in application. For example, Yu (2008) conducts a case study to examine the social impact of Reebok's codes of conduct on upholding labour standards. The author reveals that despite the implementation of ethical sourcing codes of conduct, Chinese workers are forced to work harder and faster while earning less payment, which is contrary to the stipulations outlined in the codes. Robinson (2010) also found that dangerous working conditions are created in the workplace in Costa Rica regardless of voluntary codes of conduct. We believe that this marginal effect is due to a lack of supplier's capabilities that allow them to meet the buyer's ethical standards. This leads us to believe that ethical sourcing codes of conduct alone are insufficient for greater supplier compliance. It should be complemented by collaborative supply chain partnerships (Frenkel and Scott 2002; Locke and Romis 2007). Research into this topic is less explored; thus future research should examine the role of collaboration with suppliers in linking the ethical codes of conduct to its compliance.

Seventh, where do more unethical issues take place? This study focuses only on ethical issues in the upstream where ethical concerns have rapidly increased. However, we are also aware of many business scandals that have occurred in the downstream supply chain as well. Unethical sales force behaviour would be an example in this context. In 2010, there was an allegation that Hewlett-Packard had paid millions of dollars in kickbacks to secure a contract in Russia (Crawford 2010). This leads us on to the following questions: using the manufacturer as the focal point, are more ethical issues occurring at the sourcing end, or do they occur downstream towards the retailers? Further, what is the difference in consequences between them? Does it differ among industries? Answering these questions should provide unique insights into this field.

Eighth, little is known about the likelihood of ethical concerns. When firms are caught engaging in unethical behaviour in supply management, do they actively change towards an ethical mindset, or it is just marketing efforts to smooth things out and not get caught again? If firms truly change once they are caught in unethical situations, its efforts would likely lower the likelihood of future ethical concerns. However, we are unaware of any existing studies that address this aspect. This lack of knowledge should be therefore dealt with in future studies. As theoretical framework, we believe that interested researchers can use the concept of organisational learning. That is, it may be interesting for future studies to examine whether learning from the ethical situations actually leads them to be more ethically responsible.

Ninth, there is a need to examine the actual effect of fair and ethical trade. As noted before, fair trade and ethical trade have played a significant role in reducing global inequalities. This statement has been supported by recent studies. For example, Ruben and Zuniga (2011) reveal the economic effect of fair trade on developing countries; specifically, the authors find that fair trade delivers economic benefits to independent producers in Northern Nicaragua. However, there is also a critique of its movement schemes (Barrientos 2000; Dolan 2008; Blowfield and Dolan 2010; Kolk 2012). Many of them point out that both schemes could not be a panacea for third-world poverty. These contradictory arguments lead us to believe there is a lack of understanding on its real economic impact. It is thus necessary for future studies to conduct a comprehensive investigation on this aspect using systematic methods like meta-analysis. It may also be worth investigating whether there is a missing link connecting the movement schemes to promoting third-world economies.

Finally, much less is known about fair and ethical trade movements in the context of OSCM. As shown in Table 7, prior studies have been conducted based on particular disciplines like development studies (e.g. Blowfield 2000; Barrientos and Smith 2007). Even though its view lies with global business, there is a dearth of studies into this aspect in the eyes of OSCM. It may be a good time to address this issue, given the fact that ethical sourcing has captured growing attention by OSCM scholars. A recent study by Karjalainen and Moxham (2013) would be one of the first efforts in this respect. The authors discuss fair trade concepts from an OSCM point of view, proposing what they call 'fair trade supply chains'. Surprisingly, we also found that most of the prior research on this topic has only used qualitative approaches (cf. Table 7). Thus, future studies should also be able to address this under-researched area by adopting quantitative methods. Such efforts should help advance our existing understanding on this field.

\section{Conclusion}

Ethical sourcing has received growing attention in academic literature. This trend is more pronounced in recent years. However, none of the research conducts an analysis showing its current status, nor does it provide insights into the evolution of this field that academics can rely on. This study provides a first systematic review of ethical sourcing studies applying the SLR and CNA methods. Such a 
combined approach, SLNA, allows for a rigorous investigation into this field of research in a more scientific and objective way. This study identifies a number of distinctive features that outline the state of the art of this particular field. The unique method also allows us to trace down the main path of the ethical sourcing literature. In addition to this, this study identifies influential articles that have played a central role within the structure of existing knowledge. This study also reveals a topical structure that describes four major research areas that have been widely discussed in this field. Overall, the results of this study provide unique insights into how this field of research has grown and evolved over the decades, opening directions for future ethical sourcing studies.

Besides these scholarly contributions, there are limitations to the present study. First of all, the major reason behind the choice of using the combined approach is to conduct an analysis of the literature in a more objective way, thereby limiting researcher bias. Despite its efforts, however, there is still a subjective view of our approach, especially in terms of selecting the most relevant articles. Nevertheless, we believe that having more than two researchers in the selection process would provide help in restricting the subjective bias. Next, this study chose the method of Search Path Count to calculate the traversal weight of the citation. This means that we have considered the number of all possible paths between each source and sink. However, when there is a need to assign more weights to specific node(s), it is necessary to change the method to other alternatives such as Search Path Link Count and Sear Path Node Pair. The former method is only recommended when early articles are relatively unimportant, while the latter method is suggested when articles at the middle of the path should receive higher traversal weights.

Open Access This article is distributed under the terms of the Creative Commons Attribution 4.0 International License (http://crea tivecommons.org/licenses/by/4.0/), which permits use, duplication, adaptation, distribution and reproduction in any medium or format, as long as you give appropriate credit to the original author(s) and the source, provide a link to the Creative Commons license and indicate if changes were made.

\section{References}

Akamp, M., \& Müller, M. (2013). Supplier management in developing countries. Journal of Cleaner Production, 56, 54-62.

Amaeshi, K. M., Osuji, O. K., \& Nnodim, P. (2008). Corporate social responsibility in supply chains of global brands: A boundaryless responsibility? clarifications, exceptions and implications. Journal of Business Ethics, 81(1), 223-234.

Andersen, M., \& Skjoett-Larsen, T. (2009). Corporate social responsibility in global supply chains. Supply Chain Management: An International Journal, 14(2), 75-86.
Appolloni, A., Sun, H., Jia, F., \& Li, X. (2014). Green procurement in the private sector: A state of the art review between 1996 and 2013. Journal of Cleaner Production, 85, 122-133.

Argenti, P. A. (2004). Collaborating with activists: How Starbucks works with NGOs. California Management Review, 47(1), 91-116.

Awaysheh, A., \& Klassen, R. D. (2010). The impact of supply chain structure on the use of supplier socially responsible practices. International Journal of Operations \& Production Management, 30(12), 1246-1268.

Baden, D. A., Harwood, I. A., \& Woodward, D. G. (2009). The effect of buyer pressure on suppliers in SMEs to demonstrate CSR practices: An added incentive or counter productive? European Management Journal, 27(6), 429-441.

Banjo, S. (2014, April 22). Squeeze play: Inside Nike's struggle to balance cost and worker safety. The Wall Street Journal, A1.

Barratt, M., Choi, T. Y., \& Li, M. (2011). Qualitative case studies in operations management: Trends, research outcomes, and future research implications. Journal of Operations Management, 29(4), 329-342.

Barrientos, S. (2000). Ethical trade and globalisation: Assessing the implications for development. Journal of International Development, 12(4), 559-570.

Barrientos, S., \& Smith, S. (2007). Do workers benefit from ethical trade? Assessing codes of labour practice in global production systems. Third World Quarterly, 28(4), 713-729.

Bird, M. M. (1989). Gift-giving and gift-taking in industrial companies. Industrial Marketing Management, 18(2), 91-94.

Blome, C., \& Paulraj, A. (2013). Ethical climate and purchasing social responsibility: A benevolence focus. Journal of Business Ethics, 116(3), 567-585.

Blowfield, M. (1999). Ethical trade: A review of developments and issues. Third World Quarterly, 20(4), 753-770.

Blowfield, M. (2000). Ethical sourcing: A contribution to sustainability or a diversion? Sustainable Development, 8(4), 191200.

Blowfield, M., \& Dolan, C. (2010). Fairtrade facts and fancies: What Kenyan fair-trade tea tells us about business' role as development agent. Journal of Business Ethics, 93(2), 143-162.

Boyd, D. E., Spekman, R. E., Kamauff, J. W., \& Werhane, P. (2007). Corporate social responsibility in global supply chains: A procedural justice perspective. Long Range Planning, 40(3), $341-356$.

Browne, A. W., Harris, P. J., Hofny-Collins, A. H., Pasiecznik, N., \& Wallace, R. R. (2000). Organic production and ethical trade: Definition, practice and links. Food Policy, 25(1), 69-89.

Browning, J., \& Zabriskie, N. B. (1983). How ethical are industrial buyers. Industrial Marketing Management, 12(4), 219-224.

Carter, C. R. (2000). Ethical issues in international buyer-supplier relationships: A dyadic examination. Journal of Operations Management, 18(2), 191-208.

Carter, C. R. (2005). Purchasing social responsibility and firm performance: The key mediating roles of organizational learning and supplier performance. International Journal of Physical Distribution and Logistics Management, 35(3), 177-194.

Carter, C. R., \& Easton, P. L. (2011). Sustainable supply chain management: Evolution and future directions. International Journal of Physical Distribution and Logistics Management, 41(1), 46-62.

Carter, C. R., \& Jennings, M. M. (2002). Social responsibility and supply chain relationships. Transportation Research Part E: Logistics and Transportation Review, 38(1), 37-52.

Chan, J., Pun, N., \& Selden, M. (2013). The politics of global production: Apple, Foxconn and China's new working class. New Technology, Work and Employment, 28(2), 100-115. 
Colicchia, C., \& Strozzi, F. (2012). Supply chain risk management: A new methodology for a systematic literature review. Supply Chain Management: An International Journal, 17(4), 403-418.

Crawford, D. (2010, April 15). H-P executives face bribery inquiries. The Wall Street Journal, B1.

de Nooy, W., Mrvar, A., \& Batagelj, V. (2011). Exploratory social network analysis with Pajek. Cambridge: Cambridge University Press.

Denyer, D., \& Tranfield, D. (2009). Producing a systematic review. In D. Buchanan \& A. Bryman (Eds.), The sage handbook of organizational research methods (pp. 671-689). London: Sage Publications.

Dolan, C. S. (2008). In the mists of development: Fairtrade in Kenyan tea fields. Globalizations, 5(2), 305-318.

Ehrgott, M., Reimann, F., Kaufmann, L., \& Carter, C. R. (2011). Social sustainability in selecting emerging economy suppliers. Journal of Business Ethics, 98(1), 99-119.

Eisenhardt, K. M. (1989). Building theories from case study research. Academy of Management Review, 14(4), 532-550.

Eltantawy, R. A., Fox, G. L., \& Giunipero, L. (2009). Supply management ethical responsibility: Reputation and performance impacts. Supply Chain Management: An International Journal, 14(2), 99-108.

Foerstl, K., Reuter, C., Hartmann, E., \& Blome, C. (2010). Managing supplier sustainability risks in a dynamically changing environment-Sustainable supplier management in the chemical industry. Journal of Purchasing and Supply Management, 16(2), 118-130.

Ford, J. B., LaTour, M. S., \& Henthorne, T. L. (2000). Cognitive moral development and Japanese procurement executives: Implications for industrial marketers. Industrial Marketing Management, 29(6), 589-600.

Frenkel, S. J. (2001). Globalization, athletic footwear commodity chains and employment relations in China. Organization Studies, 22(4), 531-562.

Frenkel, S. J., \& Scott, D. (2002). Compliance, collaboration, and codes of labor practice: The Adidas connection. California Management Review, 45(1), 29-49.

Gallear, D., Ghobadian, A., \& Chen, W. (2012). Corporate responsibility, supply chain partnership and performance: An empirical examination. International Journal of Production Economics, 140(1), 83-91.

Genovese, A., Koh, S. C. L., Bruno, G., \& Esposito, E. (2013). Greener supplier selection: State of the art and some empirical evidence. International Journal of Production Research, 51(10), 2868-2886.

Gimenez, C., \& Tachizawa, E. M. (2012). Extending sustainability to suppliers: A systematic literature review. Supply Chain Management: An International Journal, 17(5), 531-543.

Gonzalez-Padron, T., Hult, G. T. M., \& Calantone, R. (2008). Exploiting innovative opportunities in global purchasing: An assessment of ethical climate and relationship performance. Industrial Marketing Management, 37(1), 69-82.

Gopalakrishnan, K., Yusuf, Y. Y., Musa, A., Abubakar, T., \& Ambursa, H. M. (2012). Sustainable supply chain management: A case study of British Aerospace (BAe) Systems. International Journal of Production Economics, 140(1), 193-203.

Gupta, S., Verma, R., \& Victorino, L. (2006). Empirical research published in production and operations management (1992-2005): Trends and future research directions. Production and Operations Management, 15(3), 432-448.

Hawkins, T. G., Pohlen, T. L., \& Prybutok, V. R. (2013). Buyer opportunism in business-to-business exchange. Industrial Marketing Management, 42(8), 1266-1278.

Hoejmose, S. U., \& Adrien-Kirby, A. J. (2012). Socially and environmentally responsible procurement: A literature review and future research agenda of a managerial issue in the $21 \mathrm{st}$ century. Journal of Purchasing and Supply Management, 18(4), 232-242.

Hoejmose, S., Brammer, S., \& Millington, A. (2013). An empirical examination of the relationship between business strategy and socially responsible supply chain management. International Journal of Operations \& Production Management, 33(5), 589-621.

Hollos, D., Blome, C., \& Foerstl, K. (2012). Does sustainable supplier co-operation affect performance? Examining implications for the triple bottom line. International Journal of Production Research, 50(11), 2968-2986.

Hughes, A. (2005). Corporate strategy and the management of ethical trade: The case of the UK food and clothing retailers. Environment and Planning A, 37(7), 1145-1163.

Hughes, A., Buttle, M., \& Wrigley, N. (2007). Organisational geographies of corporate responsibility: A UK-US comparison of retailers' ethical trading initiatives. Journal of Economic Geography, 7(4), 491-513.

Hummon, N. P., \& Doreian, P. (1989). Connectivity in a citation network: The development of DNA theory. Social Networks, 11(1), 39-63.

Jargon, J. (2011, July 7). Starbucks workers plan Chile strike. The Wall Street Journal, B3.

Jiang, B. (2009). The effects of interorganizational governance on supplier's compliance with SCC: An empirical examination of compliant and non-compliant suppliers. Journal of Operations Management, 27(4), 267-280.

Karjalainen, K., \& Moxham, C. (2013). Focus on fairtrade: Propositions for integrating fairtrade and supply chain management research. Journal of Business Ethics, 116(2), 267-282.

Kaynak, R., \& Sert, T. (2012). The impact of service supplier's unethical behavior to buyer's satisfaction: An empirical study. Journal of Business Ethics, 109(2), 219-226.

Klassen, R. D., \& Vereecke, A. (2012). Social issues in supply chains: Capabilities link responsibility, risk (opportunity), and performance. International Journal of Production Economics, 140(1), 103-115.

Knudsen, J. S. (2013). The growth of private regulation of labor standards in global supply chains: Mission impossible for western small- and medium-sized firms? Journal of Business Ethics, 117(2), 387-398.

Kolk, A. (2012). Towards a sustainable coffee market: Paradoxes faced by a multinational company. Corporate Social Responsibility and Environmental Management, 19(2), 79-89.

Koplin, J., Seuring, S., \& Mesterharm, M. (2007). Incorporating sustainability into supply management in the automotive industry: The case of the Volkswagen AG. Journal of Cleaner Production, 15(11-12), 1053-1062.

Landeros, R., \& Plank, R. E. (1996). How ethical are purchasing management professionals? Journal of Business Ethics, 15(7), 789-803.

Lee, P. K. C., Lau, A. K. W., \& Cheng, T. C. E. (2013). Employee rights protection and financial performance. Journal of Business Research, 66(10), 1861-1869.

Leonidou, C. N., Leonidou, L. C., Coudounaris, D. N., \& Hultman, M. (2013). Value differences as determinants of importers' perceptions of exporters' unethical behavior: The impact on relationship quality and performance. International Business Review, 22(1), 156-173.

Lim, S., \& Phillips, J. (2008). Embedding CSR values: The global footwear industry's evolving governance structure. Journal of Business Ethics, 81(1), 143-156.

Locke, R. M., \& Romis, M. (2007). Improving work conditions in a global supply chain. MIT Sloan Management Review, 48(2), 54-62.

Locke, R. M., \& Romis, M. (2010). The promise and perils of private voluntary regulation: Labor standards and work organization in 
two Mexican garment factories. Review of International Political Economy, 17(1), 45-74.

Maignan, I., Hillebrand, B., \& McAlister, D. (2002). Managing socially-responsible buying: How to integrate non-economic criteria into the purchasing process. European Management Journal, 20(6), 641-648.

Maloni, M. J., \& Brown, M. E. (2006). Corporate social responsibility in the supply chain: An application in the food industry. Journal of Business Ethics, 68(1), 35-52.

Meyer, P. S., Yung, J. W., \& Ausubel, J. H. (1999). A primer on logistic growth and substitution: The mathematics of the Loglet Lab software. Technological Forecasting and Social Change, 61(3), 247-271.

Miemczyk, J., Johnsen, T. E., \& Macquet, M. (2012). Sustainable purchasing and supply management: A structured literature review of definitions and measures at the dyad, chain and network levels. Supply Chain Management: An International Journal, 17(5), 478-496.

Motwani, J., Kumar, A., \& Mohamed, Z. (1998). Ethical behavior of Indian purchasing managers. Transportation Research Part E: Logistics and Transportation Review, 34(2), 161-168.

Newman, M. E. J. (2004). Fast algorithm for detecting community structure in networks. Physical Review E, 69(6), 066133.

Newman, M. E. J., \& Girvan, M. (2004). Finding and evaluating community structure in networks. Physical Review E, 69(2), 026113

People's World. (2013). Sweatshops in America? Yes, at T-Mobile call centers. http://peoplesworld.org/sweatshops-in-america-yesat-t-mobile-call-centers/

Preuss, L. (2009). Ethical sourcing codes of large UK-based corporations: Prevalence, content, limitations. Journal of Business Ethics, 88(4), 735-747.

Randall, D. M., \& Fernandes, M. F. (1991). The social desirability response bias in ethics research. Journal of Business Ethics, 10(11), 805-817.

Rashman, L., Withers, E., \& Hartley, J. (2009). Organizational learning and knowledge in public service organizations: A systematic review of the literature. International Journal of Management Reviews, 11(4), 463-494.

Razzaque, M. A., \& Hwee, T. P. (2002). Ethics and purchasing dilemma: A Singaporean view. Journal of Business Ethics, 35(4), 307-326.

Reimann, F., Ehrgott, M., Kaufmann, L., \& Carter, C. R. (2012). Local stakeholders and local legitimacy: MNEs' social strategies in emerging economies. Journal of International Management, 18(1), 1-17.

Reuter, C., Foerstl, K., Hartmann, E., \& Blome, C. (2010). Sustainable global supplier management: The role of dynamic capabilities in achieving competitive advantage. Journal of Supply Chain Management, 46(2), 45-63.

Reuter, C., Goebel, P., \& Foerstl, K. (2012). The impact of stakeholder orientation on sustainability and cost prevalence in supplier selection decisions. Journal of Purchasing and Supply Management, 18(4), 270-281.

Roberts, S. (2003). Supply chain specific? Understanding the patchy success of ethical sourcing initiatives. Journal of Business Ethics, 44(2-3), 159-170.

Robertson, D. C., \& Rymon, T. (2001). Purchasing agents' deceptive behavior: A randomized response technique study. Business Ethics Quarterly, 11(3), 455-479.

Robinson, P. K. (2009). Responsible retailing: Regulating fair and ethical trade. Journal of International Development, 21(7), 1015-1026.

Robinson, P. K. (2010). Responsible retailing: The practice of CSR in banana plantations in Costa Rica. Journal of Business Ethics, 91(2), 279-289.
Rotting, D., Koufteros, X., \& Umphress, E. (2011). Formal infrastructure and ethical decision making: An empirical investigation and implications for supply management. Decision Sciences, 42(1), 163-204.

Ruben, R., \& Zuniga, G. (2011). How standards compete: Comparative impact of coffee certification schemes in Northern Nicaragua. Supply Chain Management: An International Journal, 16(2), 98-109.

Rudelius, W., \& Buchholz, R. A. (1979). Ethical problems of purchasing managers. Harvard Business Review, 57(2), 8-14.

Sabidussi, G. (1966). The centrality index of a graph. Psychometrika, 31(4), 581-603.

Saini, A. (2010). Purchasing ethics and inter-organizational buyersupplier relational determinants: A conceptual framework. Journal of Business Ethics, 95(3), 439-455.

Seuring, S., \& Müller, M. (2008). From a literature review to a conceptual framework for sustainable supply chain management. Journal of Cleaner Production, 16(15), 1699-1710.

Smith, S., \& Barrientos, S. (2005). Fair trade and ethical trade: Are there moves towards convergence? Sustainable Development, 13(3), 190-198.

Spence, L., \& Bourlakis, M. (2009). The evolution from corporate social responsibility to supply chain responsibility: The case of Waitrose. Supply Chain Management: An International Journal, 14(4), 291-302.

Strom, S. (1996, June 27). A sweetheart becomes suspect; Looking behind those Kathie Lee labels. The New York Times, D1.

Strozzi, F., \& Colicchia, C. (2015). Information processing and management using citation network and keyword analysis to perform a systematic literature review on green supply chain management. Journal of Scientometric Research, 4(3), 195-205.

Tadepalli, R., Moreno, A., \& Trevion, S. (1999). Do American and Mexican purchasing managers perceive ethical situations differently? An empirical investigation. Industrial Marketing Management, 28(4), 369-380.

Tate, W. L., Ellram, L. M., \& Dooley, K. J. (2012). Environmental purchasing and supplier management (EPSM): Theory and practice. Journal of Purchasing and Supply Management, 18(3), 173-188.

Taylor, M. (2011). Race you to the bottom... and back again? The uneven development of labour codes of conduct. New Political Economy, 16(4), 445-462.

Voss, C., Tsikriktsis, N., \& Frohlich, M. (2002). Case research in operations management. International Journal of Operations \& Production Management, 22(2), 195-219.

Winter, M., \& Knemeyer, A. M. (2013). Exploring the integration of sustainability and supply chain management: Current state and opportunities for future inquiry. International Journal of Physical Distribution and Logistics Management, 43(1), 18-38.

World Bank. (2015). World development indicators. http://data. worldbank.org/news/release-of-world-development-indicators-2015.

$\mathrm{Yu}, \mathrm{X}$. (2008). Impacts of corporate code of conduct on labor standards: A case study of Reebok's athletic footwear supplier factory in china. Journal of Business Ethics, 81(3), 513-529.

Zadek, S. (2004). The path to corporate responsibility. Harvard Business Review, 82(12), 125-132.

Zerbe, W., \& Paulhus, D. (1987). Socially desirable responding in organizational behavior: A reconception. Academy of Management Review, 12(2), 250-264.

Zorzini, M., Hendry, L. C., Huq, F. A., \& Stevenson, M. (2015). Socially responsible sourcing: Reviewing the literature and its use of theory. International Journal of Operations \& Production Management, 35(1), 60-109. 